Faculdade

de Ciências Econômicas UFRGS

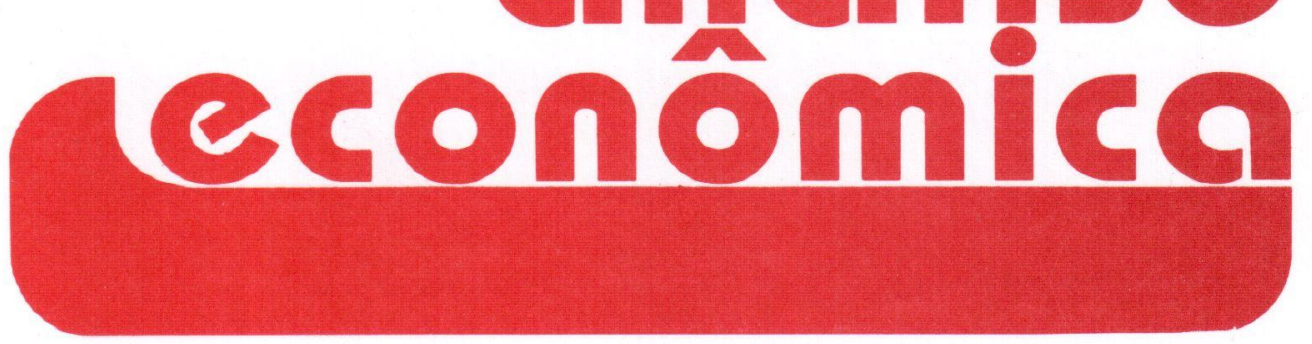

Balança Comercial e Capacidade

Produtiva da Indústria de Transformação

- Flávio Benevett Fligenspan

- Jeferson Luis Bittencourt

Breves Reflexões sobre a Relevância

da História da Teoria Econômica

- Gilberto Tadeu Lima

A Competitividade do Arroz Gaúcho

e seus Condicionantes

- Augusto M. Alvim

- Carlos G. A. Mielitz Netto

Uma Análise da Economia de Ricardo

- Liderau S. Marques Junior

A Estratégia de Substituição de

Importações Revisitada

- Alex Pereira Benício

- Joanílio Rodolpho Teixeira

The Refinements of the Orthodox Macroeconomic Theory and the Post Keynesian Theory

- Fernando Ferrari Filho

Instrumentos de Gestão Ambiental

- Jaildo Santos Pereira

- Vitor Emanuel Tavares

The Economic Implications for

Sustainable Mining

- Dina Franceschi

- James R. Kahn

Mudança Institucional e Estrutural na

Economia Brasileira do Início dos Anos Noventa

- Eduardo Simões de Almeida
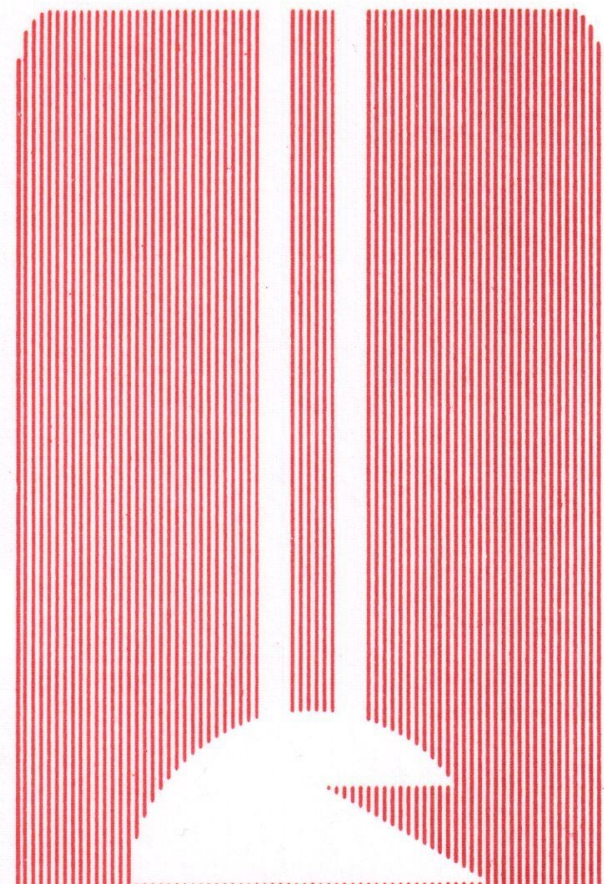

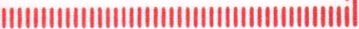
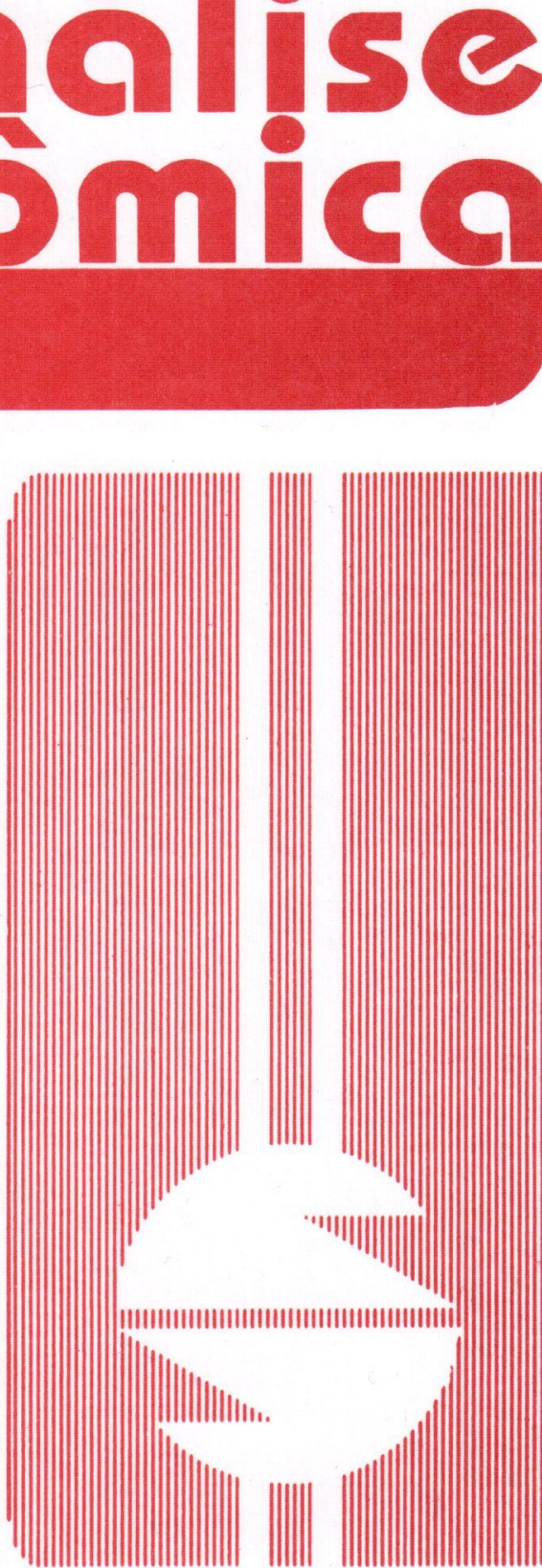
UNIVERSIDADE FEDERAL DO RIO GRANDE DO SUL

Reitora: Prof ${ }^{a}$. Wrana Maria Panizzi

FACULDADE DE CIÊNCIAS ECONÔMICAS

Diretora: Prof . Otilia Beatriz Kroeff Carrion

CENTRO DE ESTUDOS E PESQUISAS ECONÔMICAS

Diretor. Prof. Fernando Ferrari Filho

DEPARTAMENTO DE CIÊNCIAS ECONÔMICAS

Chefe: Prof. Luiz Alberto Oliveira Ribeiro de Miranda

CURSO DE PÓS-GRADUAÇÃO EM ECONOMIA

Coordenador. Prof. Marcelo Savino Portugal

CURSO DE PÓS-GRADUAÇÃO EM ECONOMIA RURAL

Coordenador. Prof. Carlos Guilherme A. Mielitz Netto

CONSELHO EDITORIAL: Achyles B. Costa, Aray M. Feldens, Carlos A. Crusius, Carlos G. A. Mielitz Netto, Eduardo A. Maldonado Filho, Eduardo P. Ribeiro, Eugênio Lagemann, Fernando Ferrari Filho, Gentil Corazza, Marcelo S. Portugal, Nali J. Souza, Otília B. K. Carrion, Paulo A. Spohr, Paulo D. Waquil, Pedro C. D. Fonseca, Roberto C. Moraes, Ronald Otto Hillbrecht, Stefano Florissi, Eleutério F. S. Prado (USP), Fernando H. Barbosa (FGV/RJ), Gustavo Franco (PUC/RJ), João R. Sanson (UFSC), Joaquim P. Andrade (UnB), Juan H. Moldau (USP), Paul Davidson (Univ. of Tennessee), Werner Baer (Univ. of lllinois).

COMISSÃO EDITORIAL: Eduardo Augusto Maldonado Filho, Fernando Ferrari Filho, Gentil Corazza, Marcelo Savino Portugal, Paulo Dabdab Waquil; Roberto Camps Moraes.

EDITOR: Gentil Corazza

EDITOR ADJUNTO: Pedro Silveira Bandeira

SECRETARIA: Fábio Sparremberger. Revisão de textos: Vanete Ricacheski.

FUNDADOR: Prof. Antônio Carlos Santos Rosa

Os materiais publicados na revista Análise Econômica são da exclusiva responsabilidade dos autores. É permitida a reprodução total ou parcial dos trabalhos, desde que seja citada a fonte. Aceita-se permuta com revistas congêneres. Aceitam-se, também, livros para divulgação, elaboração de resenhas e recensões. Toda correspondência, material para publicação (vide normas na terceira capa), assinaturas e permutas devem ser dirigidos ao seguinte destinatário:

PROF. GENTIL CORAZZA

Revista Análise Econômica - Av. João Pessoa, 52 CEP 90040-000 PORTO ALEGRE - RS, BRASIL 


\title{
THE REFINEMENTS OF THE ORTHODOX MACROECONOMIC THEORY AND THE POST KEYNESIAN THEORY: BRINGING BACK THE DEBATE BETWEEN KEYNES AND CLASSICALS ${ }^{*}$
}

\author{
Fernando Ferrari Filho**
}

\begin{abstract}
In the light of post Keynesian theory, the articles aims at showing that the principal theoretical questions and results of new classical models and new Keynesian models are inconsistent with the basic characteristics of modern entrepreneurial economies and, as a consequence, they cannot help us to understand the dynamic process of the real world. Besides, it shows that the present debate between post Keynesians and mainstream economists brings back an old discussion befween Keynes and classical economists.
\end{abstract}

AEA Code: 020

Key words: New classical and new Keynesian theories; (post)Keynesian theory; money, uncertainty and effective demand.

\section{RESUMO}

O artigo, à luz da teoria pós-keynesiana, objetiva mostrar que a teoria macroeconômica ortodoxa, mainstream, apesar de seu refinamento teórico, é inconsistente com as características das modernas economias empresariais e, por conseguinte, não consegue explicar a dinâmica do mundo real. $\mathrm{O}$ artigo, ainda, sinaliza que o atual debate macroeconômico entre mainstream e pós-keynesianos é uma extensão do debate entre Keynes e os economistas clássicos, então observado há mais de sessenta anos.

Cód. AEA: 020

Palavras-chave: Teorias novo-clássica e novo-keynesiana; teoria (pós)keynesiana; moeda, incerteza e demanda efetiva.

\footnotetext{
* I am grateful to Prof. Philip Arestis who made important comments. I also would like to thank two anonymous referees. Of course, all remaining erros are mine.

"* Professor of Economics at the Federal University of Rio Grande do Sul.
}

Análise Econômica

ANO 17

N. 31

Março/99

p. $100-110$ 


\section{1 - INTRODUCTION}

In 1980, Robert Lucas Jr., in The death of Keynesian economics: issues and ideas, argued that Keynesian models have some econometric failures due to the fact that they could not predict the value of certain economic variables (e.g. the levels of output and employment and the price level). As such, Keynesian economics was dead. However, in 1992, N.G.Mankiw, in The reincarnation of Keynesian theory, "brought back" Keynes through the microfoundations of Keynesian economics. Since then, the debate on macroeconomics, i.e. the controversies in mainstream approach ${ }^{1}$, has followed the basic ideas of Lucas and Mankiw that are identified with new classical economics and new Keynesian economics, respectively.

Post Keynesians have attempted to recover the revolutionary character of Keynesian theory - that is to say, the idea that in a monetary capitalist economy there is always a lack of aggregate demand and, as a result, unemployment - to understand that the discussion in macroeconomic theory should be located in the dynamic characteristics of the real world (Davidson, 1994:2).

Well, this article has a basic purpose: after presenting the main theoretical questions and results of new classical models and new Keynesian models, it aims at arguing, in the light of the post Keynesian theory, that these models have a great number of weaknesses to analyze and explain the dynamic characteristics of modern entrepreneurial economies. In other words, the main purpose of this article is to show that new classical models and new Keynesian models do not help us so much to understand and solve the problems of real economic world. The article proceeds as follows: Section 2 summarizes, so briefly, the basic ideas and analytical structure of new classical models and new Keynesian models. Section 3 shows, according to the post Keynesian approach, that the mainstream macroeconomic theory misrepresents the economic analysis of a capitalist economy, as well as it involves some logical inconsistencies when compared with Keynes's theoretical analytical structure. In section 4 , some conclusive comments are presented.

\footnotetext{
' Mainstream approach is related on optimization behavior by economic agents, i.e. utility maximization and profit maximization are the main reasons of economic agents.
} 


\section{2 - THE REFINEMENTS OF THE ORTHODOX MACROECONOMIC THEORY}

\section{1 - The new classical theory}

In the 1970s, Lucas Jr. $(1972,1973)$, Sargent $(1973,1975)$ and Wallace (1975), among others, introduced some theoretical propositions into the orthodox classical theory, such as (i) the rational expectation hypothesis ${ }^{2}$, and (ii) the aggregate supply hypothesis, to emphasize the idea that all markets in the economy continuosly clear in line with the Walrasian equilibrium tradition $^{3}$.

The first hypothesis argues that economic agents use all available information and know the stochastic process which determines the behavior of the variables in each period of time. In this situation, the expectations of economic agents about the future value of the economic variables are not biased.

The aggregate supply hypothesis argues that (i) the rational decisions of economic agents, workers and firms, reflect optimizing behavior, and (ii) the supply of labor and output offered by workers and firms depends upon relative prices.

The introduction of the rational expectation and aggregate supply hypotheses into the market-clearing macroeconomic models produced two important policy conclusions: first, the monetary policy is superneutral and, secondly, only microeconomic policy is able to increase aggregate supply.

Why is money superneutral? Assuming that agents are rational, when the monetary authority decides to expand the money supply, the economic agents, before making their expectations, will take this information into account and, as a result, anticipate the effects of the increase in the money supply. Thus, output and employment will not change. In this situation, the trade-off, either temporary or permanent, between inflation and unemployment is rejected by the new classical economists; that is to say, there is no Phillips curve either in the short or long run.

What kind of microeconomic policy is required to increase aggregate supply? According to the new classicals, the microeconomic policy must create incentives for firms and workers to supply more output and labor. How? The government must (i) reduce the marginal tax rates and social

\footnotetext{
${ }^{2}$ Although initially developed by Muth (1961), the rational expectations hypothesis was incorporated into macroeconomic theory through the works of Lucas $(1972,1973)$, Sargent $(1973,1975)$ and Wallace (1975).

${ }^{3}$ According to the Walrasian equilibrium tradition, prices are free to adjust instantaneously to clear markets.
} 
security benefits, (ii) permit the flexibility of wages and working practices, (iii) privatize, and so on.

Given that demand shock, specifically monetary shock, is neglected and only microeconomic policy matters, how do the new classicals explain fluctuations in output and unemployment levels in the real world? According to the new classicals, cyclical fluctuations in real output can be explained due to technological and productivity changes in the economy. Then, the new classical model is associated with the real business cycle model which emphasizes the real supply-side to explain economic fluctuations.

Considering that cyclical fluctuations are explained by aggregate supply and taking into account the fact that new classical models assume that the economic system is always self-correcting, there is no doubt that the classical and new classical theories have the same basic foundations: the natural rate of unemployment replaces the Say's law and the superneutrality of money emphasizes the quantity theory of money. It follows from this conclusion that the new classical model attempts to bring back the same assumption of "old" classical economics that Keynes criticized and rejected in his The general theory of employment, interest, and money (hereafter referred as to $G T$ ), many decades ago: the invisible hand assumption as the heart of economic analysis.

\section{2 - The new Keynesian theory}

New Keynesian theory, developed during the 1980s in response to new classical theory, aims at presenting a theoretical structure, based on the microeconomic foundations of Keynesian economics, critical of the new classical models. According to new Keynesians, the new classical theory does not provide a consistent explanation why labor and output supply functions do not change when there are demand shocks. This new Keynesian structure investigates what the new Keynesians believe to be the essential aspect of Keynes's theory: the existence of price and wage rigidities. Mankiw and Romer state,

[b]ecause wage and price rigidities are often viewed as central to Keynesian economics, much effort was aimed at showing how these rigidities arise from the microeconomics of wage and price setting (1991:1; italic added).

Thus, the new Keynesians concentrate their attention on price and wage rigidities in order to develop equilibrium models in which the economic system is non-market-clearing. Going in this direction, the new Keynesians have built a theory of aggregate supply in which wage and price rigidities can be rationalized ${ }^{4}$. Why are prices and wages sticky? What are the mac-

\footnotetext{
${ }^{4}$ It means that the new Keynesian models analyze wage and price rigidities based on maximizing behavior and rational expectations.
} 
roeconomic implications when prices and wages are sticky? The new Keynesian theory tries to answer these questions.

Gordon (1990) and Greenwald and Stiglitz (1993) identify some insights of the new Keynesian theory. Wage rigidity is explained by models related to disequilibrium in the labor market, such as efficiency wages, implicit contracts and insider-outsider workers. On the other hand, price rigidity is explained by models related to imperfect competition in the goods market, such as the high marginal costs of price adjustment.

Since labor is not a homogenous good, the models of efficiency wages suppose that labor's productivity is affected by the wage paid by firms. If the quality of workers is related to the wages received, any wage reduction proposed by firms will cause a fall in labor's productivity; as a result, profit falls, too. In this situation, firms will not cut wages when demand declines. Hence, unemployment results.

The models of implicit contracts argue that, in a context in which the workers are risk averse and have limited access to the financial markets, firms offer them an insurance against income fluctuations by stabilizing their real wages. If work contracts are negotiated according to this "clause", fluctuations in the level of output do not cause changes in real wages. In other words, according to the implicit contract models, the wage rate not only represents payment for labor services but also represents an insurance against the risk of fluctuations in the levels of income and output due to exogenous shocks.

The insider-outsider workers model examines the implications of what happens when workers have some bargaining power. According to this model, the labor market is characterized by hired workers (insiders) and unemployed workers (outsiders). Assuming that the insider workers have some bargaining power, there is a "tacit consensus" between firms and employed workers which militates against wage reduction in the face of reductions in aggregate demand. Under this circumstance, firms accept the constant wage demand of insider workers because the substitution of an outsider for an insider involves high costs of hiring and training for the firms. Further, this high cost of substitution provides insider workers with bargaining power to avoid dismissal and wage reduction.

The models of cost and price adjustment, so-called menu costs, consider that, according to Mankiw, the firm "sets its price in advance, and changes that price ex post only by incurring a small menu cost" (1985:530). Even if there are demand fluctuations, therefore, prices do not adjust in the short run because there are some costs involved in changing prices. In other words, the concept of menu costs implies that firms are price-setters and have monopoly power. 
To sum up, the new Keynesian models show that economic fluctuations occur due to the fact that prices and wages do not adjust promptly to their new market-clearing conditions. In other words, the new Keynesians argue that recession result from a failure of coordination ${ }^{5}$.

What are the policy implications of the new Keynesian models? To reduce the economic power of firms and unions, the government must promote a set of policies, such as: to reform the industrial relations, to improve labor and capital mobilities, to reduce the hiring and firing costs of labor, and so on.

It is important to emphasize that the disequilibrium theory, developed during the 1970 s, also investigates the implications of price and wage rigidities in general equilibrium analysis. However, the originality of the new Keynesian theory lies in the attempt to find a consistent microeconomic theory of price and wage rigidities, showing how the economic agents optimize their behavior under such imperfections; that is to say, new Keynesians make use of rational expectations to demonstrate "policy ineffectiveness" in the long run.

\section{3 - THE PRINCIPLES OF A MONETARY ECONOMY AND THE POST KEYNESIAN CRITIQUE OF MAINSTREAM MACROECONOMIC THEORY}

From the end of the Second World War to the beginning of the 1970s, the macroeconomists accepted the Keynes's idea that laissez-faire was not able to keeping the economy in the full employment equilibrium. As a consequence, an institutional action was necessary to regulate the levels of aggregate demand and employment ${ }^{6}$.

In the 1930s, Keynes convinced himself that a new theoretical interpretation of a modern capitalist economy was necessary to confront the traditional view of classical economists. Keynes (1973a:486-9) expressed this idea in the following passage:

On the one side are those who believe that the existing economic system is, in the long run, a self-adjusting system .... On the other side ... are those who reject the idea that the existing economic system is, in any significant sense, self-adjusting ... The strenght of the self-adjusting school depends on its having behind it almost the whole body of organised economic thinking and doctrine of the last hundred years .... Thus, if the heretics on the other side ... are to demolish the forces of ninettenth-century orthodoxy ... they must attack them ... Now I range myself with the heretics

\footnotetext{
${ }^{5}$ According to the coordenation failure assumption, firms have to choose a price strategy without knowing the price strategy the other firms while union leaders must negotiate wages taking into account the wages other unions will gain.

${ }^{6}$ In Keynes's words, a "comprehensive socialisation of investment ... [would be] the only means of securing an approximation to full employment" (1964:378).
} 
In this context, unlike the classical approach, Keynes presents a theoretical analytical structure in which the levels of output and employment are determined by effevtive demand ${ }^{7}$ and not by the labor market. In focusing upon the principle of effective demand, Keynes develops the idea of monetary theory of production ${ }^{8}$; that is to say, fluctuations in effective demand and unemployment appear because, when the future is uncertain, people decide to hold money as a store of value and, as a consequence, they postpone their expenditure decisions. In Keynes's words, "booms and depressions are phenomena peculiar to an economy in which ... money is not neutral" (Ibid.:411, italics added).

This important insight of Keynes is recovered and reinterpreted by the post Keynesian theory: the post Keynesians have grounded their ideas in the problems of money. Thus, the post Keynesian theory brings back the main Keynes's GT message: in the real world unemployment occurs because money is not neutral. Davidson (1994:17-8), for instance, has demonstrated Keynes's revolution in a context which the economic system presents the following characteristics: (i) money matters in both the short-run and long-run, (ii) the future is uncertain, (iii) contracts are denominated in money terms, (iv) money has two specific properties that differentiate it from the other producible goods, and $(v)$ unemployment in an monetary or entrepreneurial economy, i.e. an economy in which fluctuations of effective demand are explained as a monetary phenomenon, is a normal occurrence.

To explain the essence of Keynes's revolution, post Keynesians explore Keynes's Collected Writings, specially the first drafts of the GT, Chapter 17 of the GT and 1937 Keynes's article. The general theory of employment. Thus, they emphasize the uncertainty-money-unemployment link.

According to the post Keynesians, in Chapter 17 of the GT Keynes develops this linked proposition. For Keynes, money has two essential properties which follow from the existence of uncertainty: on the one hand, money's elasticity of production is zero (or negligible); that is to say, money is not producible by the use of labor in the private sector. Secondly, money's elasticity of substitution with respect to the products of industry is also zero (or negligible); that is to say; any producible good cannot replace money as a liquid store of value when the relative price of money increases. Both characteristics are crucial to explain why money is liquid par excellence.

Given these elasticity properties, effective demand failures occur due to, in the face of greater uncertainty, an increased demand for money. As a consequence, it will result in a decreased demand for labor production. In

\footnotetext{
${ }^{7}$ The theory of effective demand is explained by three propositions: (i) the theory of income determination, (ii) the theory of investment, and (iii) the theory of interest rate.

${ }^{8}$ For an interesting analysis on monetary theory of production, see Cardim de Carvalho (1992: Chapter 3).
} 
other words, in a world where the future becomes more uncertain and, as a result, people cannot predict it, unemployment equilibrium can always appear because people decide to increase their demand for liquid assets, specially money that has a substantial liquidity premium, at the expense of purchasing producible goods. Thus, entrepreneurs, following their animal spirits ${ }^{9}$, decrease employment hiring.

In the light of this idea, the post Keynesian critique of new classical and new Keynesian theories has been concentrated on (i) neutrality of money, (ii) rational expectations, (iii) equilibrium analysis, and (iv) price and wage rigidities.

The monetary theory of new classical and new Keynesian theories is essentially different from Keynes's monetary theory. In Keynes, money is never neutral, i.e. it affects the production process of an economy moving through time, subject to uncertainty and possibilities of errors (Chick, 1984). Thus, the decision to hold money allows economic agents to postpone their irreversible decisions related to investment, consumption, and so on. Contrarily, the new classical and new Keynesian economists accept, at least in the long run, the neutrality of money. Davidson (1994:301), for instance, argues that new Keynesian economics assumes that money is "neutral in the long run but not in the short run ... By contrast, new classical economists claim that money is neutral even in the short run".

Do economic agents form their expectations based on an ergodic stochastic process ${ }^{10}$ ? Answering this question, post Keynesians criticize the rational expectation hypothesis. Davidson (1982-83:188-9), for instance, argues that rational expectation hypothesis denies the risk-uncertainty distinction developed by Keynes. The new classical and new Keynesian models reduce uncertainty to a situation of risk, while Keynes shows that people form their expectations as uncertain knowledge ${ }^{11}$. In Keynes's words, in an uncertain world,

human decisions affecting the future, whether personal or political or economic, cannot depend on strict mathematical expectation, since the basis for making such calculations does not exist (1964:162-3)

Thus, for post Keynesians, rational expectations cannot hold in the real world because in the real world economic agents do not form expectations according to risk situation where the probability distribution is known, but they form them in a context which uncertainty has no known probability dis-

\footnotetext{
${ }^{9}$ According to Keynes, animal spirits means the exogenous expectations of entrepreneurs related to their investment expenditures.

${ }^{10}$ In an ergodic stochastic process the expected value of a probability distribution can be always estimated from past observation. Thus, according to the ergodic stochastic process, the world is unique and repetitive.

"See, for instance, Keynes (1973b:113-4).
} 
tribution. Besides, if uncertainty could be reduced to risk then the economic problems would disappear.

Concerning about equilibrium analysis, the Keynesian economics operates in historical time where the past is immutable and the future is uncertain on unknowable. In this context, economic agents face their expectations and commit contracts which are denominated in money ${ }^{12}$. On the other hand, according to the new classical and new Keynesian models the stability of equilibrium is ground in a context which, given the past as a reference, there is a perfect foresight due to the absence of uncertainty. Keynes (1973b:115) was critical on this notion of equilibrium, i.e. logical time: "one of these pretty, polite techniques which tries to deal with the present by abstracting from the fact that we know very little about the future".

The new Keynesian economists believe that, at least in the short run, Keynesian unemployment occurs solely due to the fact that prices and wages are sticky. In other words, the new Keynesians argue that it is supply constraints and not an insufficiency of effective demand that causes unemployment.

Despite the fact that in Chapter 3 of the GT Keynes assumes, only to simplify his analysis about the principle of effective demand (1964:27), that prices and wages are inflexible in the short run, this is neither a necessary nor a sufficient condition to explain Keynesian involuntary unemployment. The following passages from the GT show that Keynesian disequilibrium can occur even when prices and wages are flexible:

the Classical Theory has been accustomed to rest the supposedly self-adjusting character of the economic system on an assumed fluidity of money-wages; and, when there is rigidity, to lay on this rigidity the blame of maladjustment .... A reduction in money-wage is quite capable in certain circumstances of affording a stimulus to output, as the classical theory supposes. My difference from this theory is primarily a difference of analysis (Ibid , 257; italic added).

There is ... no ground for the belief that a flexible wage policy is capable of maintaining a state of continuos full employment ... The economic system cannot be made self-adjusting along [this line] (Ibid.: 267; italics added).

In light of these quotations, it is difficult to accept the idea that, in the Keynes's GT, price and wage rigidities are the cause of the underemployment equilibrium. In other words, according to Keynes's analysis, whatever the conditions of supply are, unemployment equilibrium can always occur. Further, the new Keynesian models provide only an explanation of the lack of variability in prices and wages, but do not explain unemployment equilibrium.

\footnotetext{
12 Why the contracts are expressed in money? Because money is the link between the past and the present and also between the present and the future.
} 


\section{4 - CONCLUSION}

Many years ago Keynes criticized and rejected the mainstream economic theory, i.e. classical orthodoxy ${ }^{13}$. Showing that classical theory was not able to explain the unemployment rate during the Great Depression, Keynes created a new approach to show that capitalism is unstable.

In examining the contemporaneous debate between mainstream macroeconomic theory and post Keynesian theory, there is no doubt that this debate has brought back the same questions that Keynes, in the 1930s, presented to challenge the classical economists.

Concerning the mainstream macroeconomics, it is important to note that, like the classical orthodoxy, new classicals and new Keynesians, despite some divergences, believe that, in the long run, the "invisible hand" and free market still continue to be the solution for keeping the economy at its long-run full employment equilibrium. Mankiw (apud Davidson, 1994:1), for instance, states that "classical theory is right in the long run ... [and] the long run is not so far away". In other words, mainstream macroeconomics is characterized by its faith in the market.

Post Keynesians, recovering the revolutionary character of Keynesian theory, emphasize two implications of entrepreneurial economies: (i) the relation between markets and money contracts, and (ii) the rule of institutions in the economic process. Thus, in a context where there are effective demand failures, both implications are fundamental to lead the economy to, paraphrasing Keynes, an "approximation to full employment". In Davidson's words,

"the existence of a State organization that enforces the discharge of contractual commitments is essential in providing the public with assurances of the continuity of contractual arrangements between the present and the future; an assurance that is necessary if one is going to hold money as a store of value" (op cit.:102).

Can the "invisible hand" restore the economy to its equilibrium at full employment? Or is the (post)Keynesian revolution still important to explain and, maybe, solve the effective demand failures in the world's economy?

Looking at some macroeconomic figures, such as GDP growth rate and the inflation rate, it is possible to conclude that during the period in which the policy makers adopted Keynesian macroeconomic policies, i.e. from the end of the Second World War to the beginning of the 1970s, the world's econ-

\footnotetext{
${ }^{13}$ In Keynes's words, "the weight of my criticism is directed against the inadequacy of the theoretical foundations of the laissez-faire doctrine upon which I was brought up and which for many years I taught" (1964:339).
} 
omy was stable; that is to say, the economic system was around full employment equilibrium and the inflation rate was under control. By contrast, in the present globalization process, in which the (neo)liberal capitalism restrains and rejects the macroeconomic actions of National States, the financial-monetary crisis has been observed and, as a result, unemployment has become a real problem.

In this context, despite the fact that (i) the debate in macroeconomic theory has been identified with new classical economics and new Keynesian economics, and (ii) the policy makers have adopted the principles of traditional economic theory for keeping the economic system to its full employment output, the direction of economic system cannot neglect (post)Keynesian's revolutionary analysis because this theory has demonstrated the theoretical weakness of mainstream macroeconomics. Thus, the main message of this article is to show that post Keynesian theory, as Keynes long time ago criticized and rejected the classical theory, has also strong fundamentals to ask and deny the theoretical refinements of orthodox theory that metamorphoses itself with the adjective "new". 


\section{REFERENCES}

CARDIM DE CARVALHO, F. Mr.Keynes and the post keynesians: principles of macroeconomics for a monetary production economy. Aldershot: Edward Elgar, 1992.

CHICK, V. Macroeconomics after Keynes: a reconsideration of the General Theory. Cambridge: The MIT Press, 1984.

DAVIDSON, P. Rational expectations: a fallacious foundation for studying crucial decisionmaking processes. Journal of Post Keynesian Economics, 5(2), p.182-98, Winter 1982-83.

Post Keynesian macroeconomic theory. Aldershot: Edward Elgar, 1994.

GORDON, R. What is new-keynesian economics? Journal of Economic Literature, 28, p.1115-71, Sept. 1990.

GREENWALD, B. \& STIGLITZ, J.E. New and old keynesians. Journal of Economic Perspectives, 7(1), p.23-44, Winter 1993.

KEYNES, J.M. The General theory of employment, interest, and money. New York: HBS Book, 1964.

The general theory and after: preparation. London: Macmillan (The collected writings of John Maynard Keynes, MOGGRIDGE, D. (ed), v.XIII), $1973 a$.

The general theory and after: defence and development. London: Macmillan (The collected writings of John Maynard Keynes, MOGGRIDGE, D. (ed). v.XIV), 1973b.

LUCAS Jr., R. Expectations and the neutrality of money. Journal of Economic Theory, 4(2), p.103-24, April 1972.

Some international evidence on output-inflation trade-offs. American Economic Review, 63(3), p.326-34, June 1973.

The death of keynesian economics: issues and ideas. Chicago: University of Chicago Press, Winter 1980.

MANKIW, N.G. Small menu costs and large business cycles: a macroeconomic model of monopoly. Quarterly Journal of Economics, 100, p.529-39, May 1985.

MANKIW, N.G. \& ROMER, D. (eds.) New keynesian economics. Cambridge: MIT, 1991.

MUTH, J. Rational expectations and the theory of price movements. Econometrica, 29 p.315-35, July 1961

SARGENT, T. Rational expectations, the real rate of interest, and the natural rate of unemployment. Brookings Papers on Economic Activity, 2, p.429-80, 1973.

SARGENT, T. \& WALLACE, N. "Rational" expectations, the optimal monetary instrument, and the optimal money supply rule. Journal of Political Economy, 83(2), p.241-54, April 1975. 